\title{
Ultrasonographic Study of Ascites with Clinicopathological Correlation
}

\author{
Dr. Rathin Kumar Ghoshal Md ${ }^{1,}$ Dr. Kedarnath Pal Md \\ ${ }^{1}$ Consultant Radiologist, ${ }^{2}$ Assistant Professor R.G. Kar Medical College Kolkata
}

\section{Introduction}

'Ascites' means collection of excessive free fluid in the peritoneal cavity. Ascites is a manifestation of various number of diseases and the aetiopathogenesis of ascites is varied

Clinically ascites can be recognized when the amount of fluid exceeds $1500 \mathrm{ml}$. Ultrasound can detect as little as 100 mililitres in the common sites i.e. hepatorenal recess and pelvic cul-de-sac (normal fluid amount $=50 \mathrm{ml}$ ).

Ultrasound performs better than $\mathrm{CT}$ in localizing asceitic fluid in relation to peritoneal spaces becauses it allows instant visualization in different planes. Ultrasound is also less hazardous in relation to CT. it involves minial patient's preparation and additionally is the least expensive of available imaging tests It can also be performed in very sick non ambulatory patients at beside.

Diagnosis often requires fine needle percutaneous aspiration associated with cytopathological study. US guided fine needle aspiration is a simple and easy, cost effevtive and a useful procedure for obtaining ascitic fluid samples. Aetiophysiological Classification of Ascites A. Ascites not associated with peritoneal disease 1. Portal hypertension :

A. Cirrhosis

B. Hepatic congestion - C. C. F

- Constrictive pericarditis

- IVC obstruction

- Hepatic vein obstruction

(Budd-Chiari syndrome)

C. Portal vein occlusion

2. Hypoalbuminaemia :
A. Nephrotic syndrome
B. Protein losing enteropathy
C. Malnutrition.

3. Miscellaneous :
A. Myxoedema
B. Ovarian disease
C. Pancreatic ascites
D. Bile ascites
E. Chylous ascites
B. Ascites Associated with Peritoneal Disease

\section{Infections :}

- Bacterial Peritonitis.

- Tubercular Peritonitis.

\section{Neoplasms:}

- Secondary malignancy

- Primary malignant mesothelioma

Pseudomyxoma peritonei.

.More than $90 \%$ of patients with ascites have cirrhosis ,neoplasm, CCF or tuberculosis.

C. Composition of Ascitic fluid in different types

From the above discussion of pathogenesis of ascites in different conditions it is evident that the compositions of ascetic fluids varies in different conditions. This can be tabulated as follows 


\begin{tabular}{llll}
\hline Parameters & $\begin{array}{l}\text { Transudative } \\
\text { ascites }\end{array}$ & $\begin{array}{l}\text { Exudative } \\
\text { ascites }\end{array}$ & $\begin{array}{l}\text { Malignant } \\
\text { ascites }\end{array}$ \\
\hline $\begin{array}{l}\text { BIOCHEMICAL } \\
\text { 1. Specific Gravity }\end{array}$ & 1.012 & $>1.018$ & $>1.018$ \\
$\begin{array}{l}\text { 2. Protein content } \\
\text { 3. Ascitic protein/ } \\
\text { Serum protein }\end{array}$ & $<0.5 \mathrm{gm} / \mathrm{dl}>\mathrm{Or}=2.5 \mathrm{gm} / \mathrm{dl}>\mathrm{Or}=2.5 \mathrm{gm} / \mathrm{dl}$ \\
$\begin{array}{l}\text { 4. Ascetic fluid } \\
\text { LDH/Serum LDH }\end{array}$ & $>0.6$ & $>0 \mathrm{Or}=0.5$ & \\
$\begin{array}{l}\text { 5. 5-A Albumin } \\
\text { gradient }\end{array}$ & $>$ or $=1.1 \mathrm{gm} / \mathrm{dl}<1.1 \mathrm{gm} / \mathrm{dl}$ & \\
\hline
\end{tabular}

CYTOLOGICAL

1. Number Few present Plentiful Moderate

2. Character

\begin{tabular}{|c|c|c|}
\hline $\begin{array}{l}\text { Nearly all } \\
\text { mesothelial } \\
\text { cells }\end{array}$ & $\begin{array}{l}\text { Imflammatory cells } \\
\text { i. e. polymorphs or } \\
\text { lymphocytes } \\
\text { depending on the } \\
\text { cause }\end{array}$ & $\begin{array}{l}\text { Malignant cells } \\
\text { may be detected if } \\
\text { concentrated } \\
\text { deposits are } \\
\text { examined }\end{array}$ \\
\hline
\end{tabular}

The aim of my study is as follows:

1. To diagnose presence of ascites by sonological study.

2. To differentiate between different types of ascites by sonological findings.

3. To arrive at a provisional diagnosis cause of ascites on the basis of sonological findings.

4. Diagnostic paracentesis of ascites fluid with us guided fine needle aspiration where necessary with ytopathological study of the ascites fluid.

5. To correlate the sonological diagnosis with the cytopthological diagnosis.

6. To identify limitation and accuracy of sonography assisted with cytopathological study of ascetic fluid in diagnosis of cause of ascites. Sonological appearance of different organs in different cases of ascites

\section{Changes In Cirrhosis Of Liver}
A. Liver changes -
1. Volume redistribution
2. Coarse echotexture
3. Nodular surface
4. Regenerating nodules

\section{B. Features of Portal Hygertension-}

Cirrhosis is the most common cause of intrahepatic portal hypertension. Sonographic findings of portal hypertension
1. Splenomegaly
2. The caliber of the portal vein
3. Ascites
4. Portosystemic venous collaterals

II. Gall Bladder Wall Thicness And Changes

III. Channges In Renal Diseases 
1. Size of kidney

2. Increased renal cortical echogenicity

3. Accentuated corticomedullary differentiation

IV. Changes In Cardiac Diseases Causing Ascites :

The cardiac diseases causing ascites are mainly constrictive pericarditis and congestive cordiac failure

1. In congestive cardiac failure the following sonological findings are seen.

(a) Enlargement of the inferior vena cava

(b) Layers of increased echogenicity

2. In constrictive pericarditis

3. In Budd-Chiari sybdrome

\section{Changes In Infective Cause Of Ascites :-}

Ascites complicated by infection may contain septations or floating debris.

In tuberculous peritonitis multiple fine echoes are seen, enlarged necrotic mesenteric nodes and echogenic epigastric masses representing caseating granulomata may be noted. The greater omentum may be thickened by granulomatous deposits and adhesions. This may appear on sonography as an "omental cake" indistinguishable from peritoneal corcinomatosis and mesothelioma.

\section{Malignant Ascites :-}

Malignant ascites may be due to following causes with the sonological findings described against each of them.

1. Lymphoma:-

a) Sonological findings :-

Mesenteric lymphoma may appear as a lobulated mass encasing the mesenteric vessels that manifest as linear echoes within the mass (sandwich sign).

2. Mesothelioma : the disease typically causes thickening of the omentum which appears sonographically as sheetlike superficial masses described as "omental mantle or cake".

3. Carcinomatosis:
A) The locations where peritoneal metastases are commonly found :-
a) Pelvic cul-de-sac.
b) The root of the mesentery.
c) The ileocaecal junction.
d) The sigmoid mesocolon.
e) The right paracolic gutter.

\section{Result And Analysis}

50 cases were included in the study. All patients had ascites as detected by ultrasonological study and the cause of ascites was correlated with the cytological and biochemical analysis of ascetic fluid. The ascetic fluid is broadly classified as transudative and exudative. The distribution of cases, based on whether the ascites was exudative or transudative, is tabulated in table I.

Table I

Case distribution according to character of ascites fluid

\begin{tabular}{lcc}
\hline Character of ascetic fluid & No. of cases & Percentage \\
\hline Transudative & 28 & $56 \%$ \\
Exudative & 22 & $44 \%$ \\
\hline Total & 50 & $100 \%$ \\
\hline
\end{tabular}


Table II

Distribution of different cases according to aetiology

\begin{tabular}{lcc}
\hline \multicolumn{1}{c}{ Diseases } & Number of cases & Percentage \\
\hline A. Trasudative & 17 & $34 \%$ \\
1. Cirrhosis of liver & 6 & $12 \%$ \\
2. Renal diseases & 5 & $10 \%$ \\
3. Cardiac diseases & & \\
B. Exudative & 7 & $14 \%$ \\
1. Infective causes & 14 & $28 \%$ \\
2. Malignant ascites & 1 & $2 \%$ \\
3. Miscellaneous & & \\
$\quad$ (Splenic rupture) & 50 & $100 \%$ \\
\hline Total &
\end{tabular}

Table III

\begin{tabular}{lcc}
\hline \multicolumn{1}{c}{ Diseases } & Male & Female \\
\hline 1. Cirrhosis of liver & 13 & 4 \\
2. Renel diseases & 3 & 3 \\
3. Cardiac causes & 2 & 3 \\
4. Infective causes & 3 & 4 \\
5. Malignant ascites & 8 & 6 \\
6. miscellaneous & 1 & 0
\end{tabular}

\begin{tabular}{|c|c|c|c|}
\hline Total & \multicolumn{2}{|c|}{30} & 20 \\
\hline \multicolumn{4}{|c|}{ Table - IV } \\
\hline Echographic findings & No of patients & Diagnosi & \\
\hline 1. Debris within fluid & 11 & $\begin{array}{c}\text { Infective ascites } \\
\text { (Tuberculous) }\end{array}$ & (4) \\
\hline 2. Septations & 2 & $\begin{array}{l}\text { Malignant ascites } \\
\text { Infective ascites } \\
\text { (Pyogenic) }\end{array}$ & $\begin{array}{l}\text { (7) } \\
\text { (1) }\end{array}$ \\
\hline & & Splenic rupture & (1) \\
\hline 3. Matted bowel loops & 11 & $\begin{array}{c}\text { Malignant ascites } \\
\text { Infective ascites } \\
\text { (tuberculous) }\end{array}$ & $\begin{array}{l}\text { (7) } \\
\text { (4) }\end{array}$ \\
\hline 4. Loculated fluid & 2 & $\begin{array}{l}\text { Splenic trauma } \\
\text { Infective ascites } \\
\text { (tuberculous) }\end{array}$ & $\begin{array}{l}\text { (1) } \\
\text { (1) }\end{array}$ \\
\hline 5. Hepatic metastasis & 5 & Malignant ascites & \\
\hline
\end{tabular}

Table - V

Sonological finding in cirrhosis of liver

\begin{tabular}{lcc}
\hline USG appearance & No. of cases & Percentage \\
\hline 1. Liver & 11 & $64.7 \%$ \\
$\begin{array}{l}\text { (a) Decrease in size } \\
\text { (Shrunken liver) }\end{array}$ & 11 & $64.7 \%$ \\
$\begin{array}{l}\text { (b) Coarse echotexture } \\
\text { (c) Nodular surface } \\
\text { (d) Regenerating nodules }\end{array}$ & 3 & $17.6 \%$ \\
2. Portal vein dilated & 1 & $5.9 \%$ \\
(diameter $>13 \mathrm{~m} . \mathrm{m})$ & 13 & $76.5 \%$ \\
3. Spleen enlarged in size & 15 & $88.2 \%$ \\
( $>12$ cm in length) & 14 & $82.3 \%$ \\
4. Splenic vein dilated & & \\
\hline
\end{tabular}




\begin{tabular}{|c|c|c|}
\hline $\begin{array}{l}\text { No. of cases with } \\
\text { Clinical diagnosis } \\
\text { Of ascites due to } \\
\text { Cirrhosis of liver }\end{array}$ & $\begin{array}{l}\text { No. of case with } \\
\text { sonological diagnosis } \\
\text { of cirrhosis of liver } \\
\text { with portal hypertension }\end{array}$ & $\begin{array}{l}\text { Cytopathological } \\
\text { diagnosis }\end{array}$ \\
\hline 23 & 17 & 16 \\
\hline
\end{tabular}

Table - VI

\begin{tabular}{lcc}
\hline \multicolumn{1}{c}{ Cause } & No. of cases & Percentage \\
\hline 1. Chronic Renal Failure & 4 & $66.6 \%$ \\
2. Diabetic nephropathy & 1 & $16.7 \%$ \\
3. Nephritic syndrome & 1 & $16.7 \%$ \\
\hline
\end{tabular}

Of these infective cases the numerical distribution of tuberculous

and pyogenic cases are listed in the following table.

Table - VII

\begin{tabular}{|c|c|c|c|c|}
\hline \multicolumn{2}{|c|}{ Case of infective } & ascites No. of cases & & Percentage \\
\hline \multicolumn{2}{|c|}{ 1. Pyogenic peritonitis } & 2 & & $28.6 \%$ \\
\hline \multicolumn{2}{|c|}{ 2. Tuberculous peritonitis } & 5 & & $71.4 \%$ \\
\hline \multicolumn{5}{|c|}{ Table - VIII } \\
\hline $\begin{array}{l}\text { Aetiology of } \\
\text { infective } \\
\text { ascites }\end{array}$ & $\begin{array}{l}\text { Total no } \\
\text { of cases }\end{array}$ & $\begin{array}{l}\text { Echographic } \\
\text { findings }\end{array}$ & $\begin{array}{l}\text { No. of } \\
\text { patients }\end{array}$ & Percentage \\
\hline
\end{tabular}

\begin{tabular}{lllll}
\hline $\begin{array}{l}\text { 1. Pyogenic } \\
\text { infection }\end{array}$ & 2 & $\begin{array}{l}\text { a) Coarse network of } \\
\text { echoes (Septations) }\end{array}$ & 2 & $100 \%$ \\
$\begin{array}{ll}\text { 2. Tuberculous } \\
\text { peritonitis }\end{array}$ & 5 & $\begin{array}{l}\text { a). Multiple fine } \\
\text { echoes within the } \\
\text { fluid (debris) } \\
\text { b) Matted bowel loops } \\
\text { c) Loculated fluid }\end{array}$ & 4 & $80 \%$ \\
& & 4 & $80 \%$ \\
\hline
\end{tabular}

TTable - IX

\begin{tabular}{lcc}
\hline $\begin{array}{l}\text { No. of clinically } \\
\text { diagnosed cases } \\
\text { suggesting ascites } \\
\text { of infective origin }\end{array}$ & $\begin{array}{l}\text { No. of cases with } \\
\text { sonological diagnosis } \\
\text { of ascites of } \\
\text { infective origin }\end{array}$ & $\begin{array}{l}\text { No. of cases cytopa- } \\
\text { thologically diagmo- } \\
\text { sed as ascites of } \\
\text { infective origin }\end{array}$ \\
\hline 5 & 7 & 7 \\
\hline & Table $-\mathbf{X}$
\end{tabular}

Sonographic findings related to malignant ascites

\begin{tabular}{lcc}
\hline \multicolumn{1}{c}{ Sonographic } & No. of patients & Percentage \\
\hline 1. Fine echoes within the & 7 & $50 \%$ \\
fluid (Debris) & 7 & $50 \%$ \\
2. Matted bowel loops & 0 & $0 \%$ \\
3. Loculated fluid & 6 & $42.8 \%$ \\
4. Hepatic metastases & 3 & $21.4 \%$ \\
5. Enlarged lymphnodes & & $28.6 \%$ \\
6. Associated intraabdminal & 4 & \\
S.O.Ls or Plevic S.O.Ls & & \\
(Adnexal/Gall Blader/ & & \\
Pancreas/ Cervix &
\end{tabular}

Table given below shows the comparative efficiency of different diagnostic modalities in ascites. 
Table - XI

\begin{tabular}{ccc}
\hline $\begin{array}{l}\text { Clinically diagnosed } \\
\text { malignant ascites }\end{array}$ & $\begin{array}{l}\text { Sonologically diagnosed } \\
\text { malignant ascites }\end{array}$ & $\begin{array}{l}\text { Cytopathologically } \\
\text { diagnosed } \\
\text { malignant ascites }\end{array}$ \\
\hline 14 & 14 & 13 \\
\hline
\end{tabular}

From the above discussion USG is seen to have $100 \%$ specificity and $100 \%$ sensitivity in diagnosing cases of ascites. So we can analyse the diagnostic ability of USG in differentiating exudative or transudative types of ascites in the following table.

\begin{tabular}{|lccc|}
\multicolumn{4}{c}{ Table - XII } \\
\hline USG results & \multicolumn{2}{c}{ Diagnosis } & Total \\
& Transudative & Exudative & 31 \\
\hline $\begin{array}{l}\text { Transudative } \\
\text { (Typical sonolucent }\end{array}$ & 28 & 3 & 19 \\
$\begin{array}{l}\text { Fluid) } \\
\begin{array}{l}\text { Exudative } \\
\text { (Atypical fluid) }\end{array}\end{array}$ & 0 & 19 & 50 \\
\hline Total & 28 & 22 & \\
\hline
\end{tabular}

From above table it is found that in the differentiation of transudative from exudative fluid by USG the sensitivity is $100 \%$ and specificity is $86.4 \%$, and the positive predictive value for transudative ascites is $90.3 \%$. The efficacy of USG in determining the aetiology of ascites is compared with clinical and cytopathological procedures in the table below.

Table - XIII

\begin{tabular}{lcc}
\hline Aetiology of ascites & Total no of cases & Percentage (\%) \\
\hline $\begin{array}{l}\text { 1. As diagnosed } \\
\text { Clinically }\end{array}$ & 39 & $78 \%$ \\
$\begin{array}{l}\text { 2. As diagnosed } \\
\text { Sonological methods }\end{array}$ & 49 & $98 \%$ \\
3. As diagnosed by \\
$\begin{array}{l}\text { Cytopathological study } \\
\text { of ascites fluid } \\
\text { (whether transudative or } \\
\text { exudative and infective or } \\
\text { malignant) }\end{array}$ & 48 & $96 \%$ \\
\hline
\end{tabular}
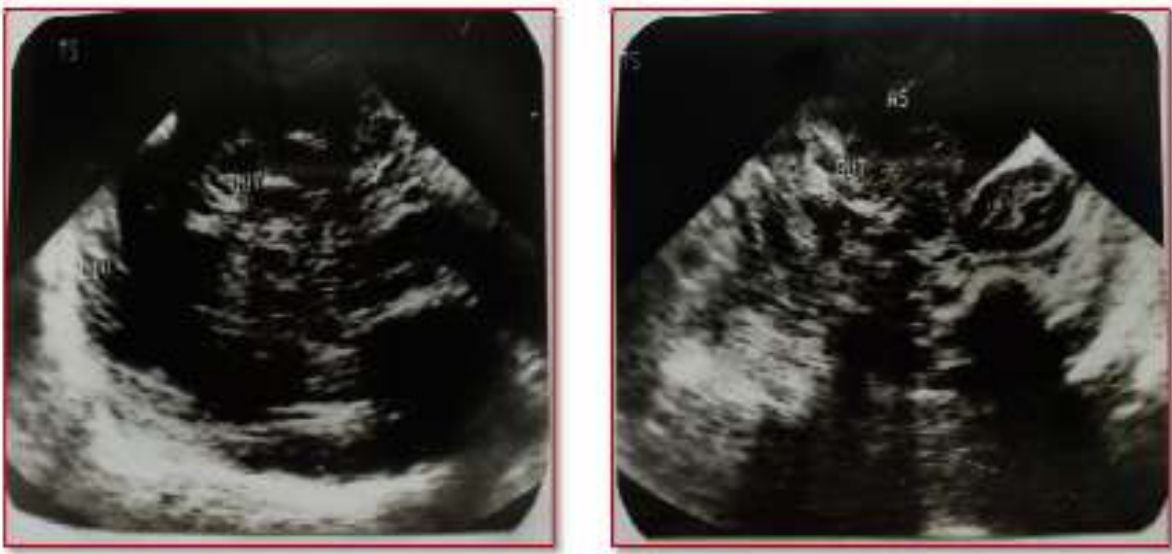

Ascites Associated With Cirrhosis With Development Of Portal Hypertension 

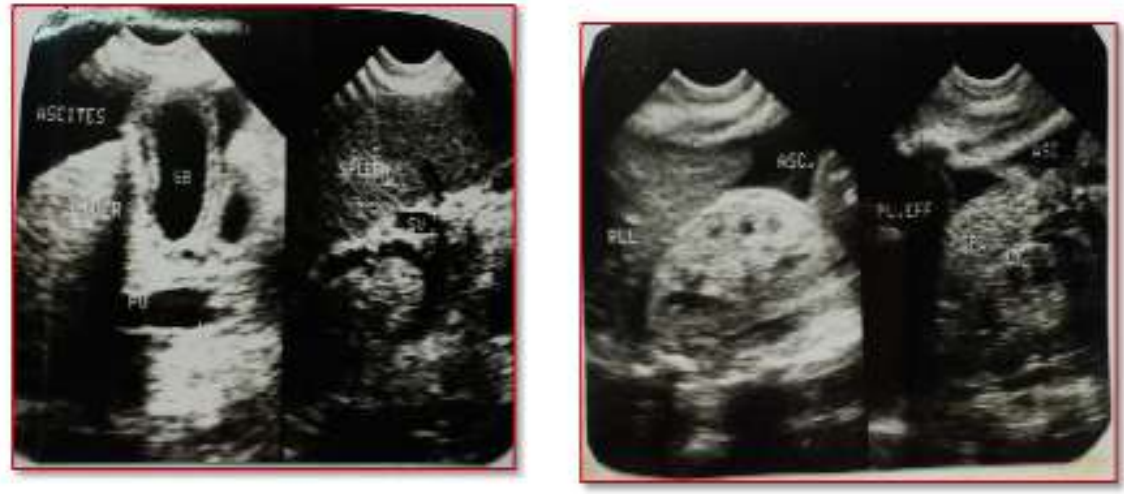

Ascites In Renal Disease

Ascites In Cardiac Disease
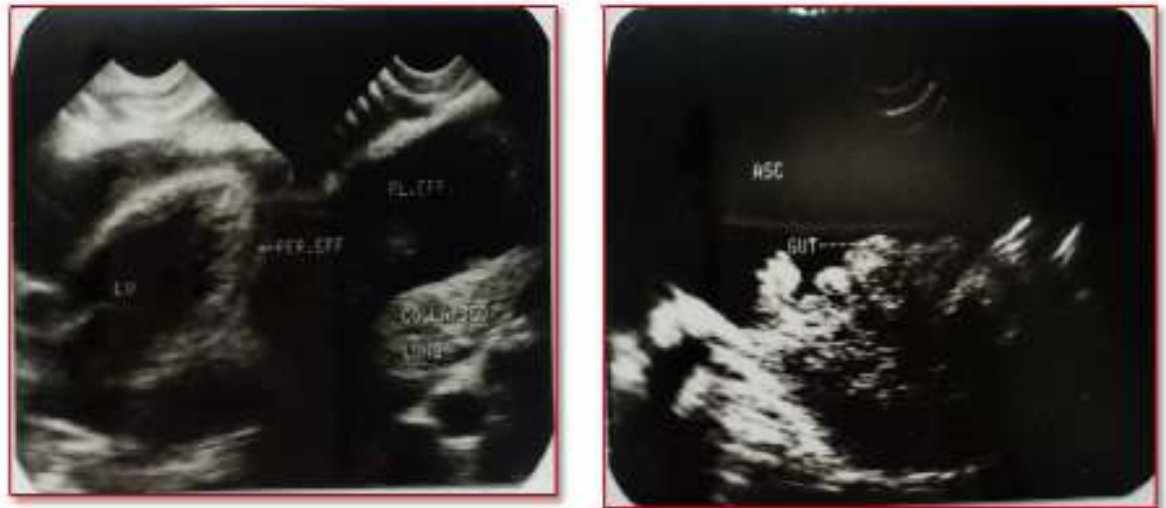

Ascites in a case of cardiac failure. There is presence of pleural effusion pericardial also.Matted gut in ascites

\section{Discussion}

The aim of my study was to establish the utility of ultrasound technique in case of ascites. This evaluation can be broadly categorized into four main subheadings :

1. To evaluate the efficacy of ascites.

2. To assess the efficacy of ultrasound in differentiating between transudative and exudative ascites.

3. To identify the value of sonological methods to diagnose the aetiology of ascites.

4. To correlate the ultras aspirated ascetic fluid to assess the efficacy of ultrosonography. Ultrasound is seen to be quite sensitive in identifying small amount of collection of ascetic fluid. peritoneal cavity can be detected by ultrasound .

In our study of the 50 cases with ascites correct diagnosis of ascites was arrived clinically in 45 cases (90\%). Ultrasound was able to confirm the diagnosis in all clinically diagnosed positive cases as well as to identify ascetic in 5 clinically undiagnosed cases (10\%).

Differentiation of benign and malignant ascites can be made sonologically.

let us discuss the role of ultrasonography in diagnosing the aetiology of ascites.

In our study of 50 cases of ascites 17 cases of cirrhosis of liver with portal hypertension were identified as cause of ascites. In renal diseases ascites is most commonly associated with nephrotic syndrome and chronic glomerulonephritis

In the cytopathological study of the ascetic fluid in renal diseases it is seen to be of transudative type. Another important aetiology of ascites is cardiac causes. The main cardiac causes leading to ascites formation is cardiac failure and constrictive pericarditis or pericardial effusion.

Infective causes of ascites constitutes Tuberculous peritonitis and pyogenic peritonitis.

USG study helped to reach causative factor in the genesis of ascites in $98 \%$ of cases whereas cytopathology of ascites the nature of the ascetic fluid was helpful in $96 \%$ of cases. On the other hand exudative type of fluid may be generated in infective or malignant ascites. On cytopathological study demonstration of malignant cells can point to a diagnosis of malignant ascites and the types of cells in the exudative fluid can point to the nature of infection in ascites. Thus the two methods are supplementary to each other. 


\section{Conclusion}

From the present study following conclusions could be drawn:

1. USG is an accurate, safe, noninvasive, sensitive and costeffective imaging modality in diagnosing ascites, even in those cases where clinical diagnosis was not possible due to minimal collection of fluid.

2. USG is also very much effective in paracentesis where the ascetic fluid is loculated, deep seated or minimal in amount.

3. USG is very much effective in differentiating between transudative and exudative fluids.

4. USG is quite efficient in arriving at a causative diagnosis as to the aetiology of the ascites by analysing the findings noted in abdominal scanning. This has quite advantage over the cytopathological study of ascitic fluid, which often cannot point out aetiology of ascites particularly in transudative ascites.

5. In some surgical cases (viz. blunt trauma abdomen) USG may

diagnose the injury to the intraabdominal organs at earliest possibility.

6. Ultrasonography is seen to be very useful in the diagnosis of cases of ascites and in some cases (viz. tuberculous peritonitis) USG guided paracentesis of fluid is of ominous help in arriving at an early diagnosis and thus in its treatment. (where the collection of fluid is minimal or deep seated or loculated).

Therefore widespread use of ultrasonography should be strongly recommended in evaluating different cases of ascites for early definitive diagnosis, which in turn helps the therapy as well.

\section{Bibliography}

[1]. Bo Ca M, Hank ak I, Mikuleck YM et al - Biochemical pattern of the ascetic fluid in liver cirrhosis and in neoplastic diseases: Gastroenterol. J 1991; 51(3-4): 136-137.

[2]. Cattau E.L. Jr. Benjamin S.B. - The accuracy of the physical examination in the diagnosis of suspected ascites: J. Amer. Med. Assoc. 247, 1164; 1982.

[3]. Dwivedi M, Misra SP, Misra V et al - Value of adenosine deaminase estimation in the diagnosis of tuberculous ascites: Am. J. Gastro, 1990; 9: 1123-1125.

[4]. Fernandez R, Doly JM: Pseudomyzoma Peritoneii Arch Surg 1980; 115: 409-414.

[5]. Goodling GAW, Cummings SR. Sonographic detection of ascites in liver disease; J. ultrasound Med 1984; 3: 169-172.

[6]. Kline M.M., Mccallum R.W. et al: The clinical value of ascetic fluid culture and leucocyte count in studies in alcoholic cirrhosis. Gastroenterology 70, 408-412; 1976

[7]. Lafortune M, Marbue D, Breton G et al. portal venous system measurements in portal hypertension. Radiology 1984; 151: 27-30.

[8]. Martin JK, JR and Foelliner JR Abdominal fluid in patients with gastrointestinal malignant lesions. Mayo Clin. Proc. 1986; 61: 467.

[9]. Merritt CB, Williams SM: Ultrasound findings in a patient with pseudomyxoma peritoneii. J. Clin. Ultrasound 1978; 6: $417-418$.

[10]. euers MA: Metastatic disease along the small bowel mesentery: roentgen features. AJR 1975; 123: 67-73.

[11]. Moertel C.G. : Peritoneal Mesothelioma. Gastroenterol 1972; 63: 346-350.

[12]. Parsons SL, Watson SA and Stelle RGC. : Malignant Ascites, British Journal of Surgery, January 1996. 17

[13]. Pillay VK: Protein relationship is serum and cavity fluids - S. Afr. Med. J. 38: 51; 1964.

[14]. Proto AV., Lane AJ., Marngola JA: A new concept of ascetic fluid distribution. AJR 1976; $126: 974$.

[15]. Runyon BA., Hoefs HC - Is the concept of "exudative" ascites useful? (Letter) Hepatology 4: 447-450; 1984

[16]. Runyon BA, Hoefs JC. , Morgan TR. : Ascitic fluid analysis in malignancy related ascites. Hepatology; $1988 ; 8: 1104-1109$.

[17]. Sander RC. : The significance of sonographic gallbladder wall thickening J. Clin. Ultrasound 1980; 8: $143-146$.

[18]. Shloer WJ., Leopld GR., Scheoble FW. : Sonography of the thickened gallbladder wall a nonspecific finding. AJR, 1981; 136: 337339.

[19]. Wu CC., Chow K.S., Lu TN, Huang F.T. : Sonographic features of tuberculous omental cakes in peritoneal tuberculous. J. Clin. Ultrasound 1988; 16: 195-198.

[20]. Yeh HC, Chahinian AP. : Ultrasonography and computed tomography of peritoneal mesthelioma. Radiology 1980; 135: 705- 712. 